\title{
1 Spatial familiness and family spatialities-searching for fertile ground between family business and regional studies
}

\author{
Rodrigo Basco and Lech Suwala
}

\section{Introduction}

Although family business and regional studies remained unconnected until a few years ago, key thinkers in both fields reminded us early on about the value added by considering space in family firms and the embeddedness of families and their firms in territories. Indeed, just in the second issue of Family Business Review in 1988, referring to family firms and community culture, Joseph Astrachan emphasised that space can act as an integrative factor in the family firm's success: 'Family businesses acquired in a manner that is at odds with the local culture will suffer, while firms that are acquired and managed in harmony with the local culture will have a higher level of morale and long-run productivity' (Astrachan, 1988, 165). Walther Isard (considered the father of regional science) formulated thoughts on future directions for the discipline by saying that a general theory of human society (as a response to Masahisa Fujita) should consider

family, social group, and political decision-making and policy formulation. The optimization type of decision-making involving the family as a basic social organization and the behavior of political groups (parties) [,] which I explored in my General Theory: Social, Political, Economic and Regional (1969) from an economist's standpoint would need to be extended greatly to be made much more realistic.

(Isard, 1999, 388)

Family firms are the most common form of organisation around the world, existing in different sizes, sectors, and locations (Basco \& Bartkevičiūte, 2016). Regardless of whether they were investigating gigantic multinational conglomerates in North America, the Middle East, and far-East Asia; small and medium Mittelstand family firms in Germany; or the vast number of family-based micro-businesses in Africa, researchers have observed that family firms (as legal, social, and economic entities) are characterised by family involvement in ownership, governance, and management, which in turn affects firm behaviour and performance (Basco, 2013). In the last 
few decades, research in family business studies has extended beyond the aforementioned classical internal variables and has begun considering external and/or surrounding variables (Discua Cruz \& Basco, 2018; GomezMejia, Basco, Müller, \& Gonzalez, 2020; James et al., 2020; Krueger, Bogers, Labaki, \& Basco, 2020). For instance, context plays an important role when understanding the idiosyncrasies of family firms, including their economic positions (Steier, Chua, \& Chrisman, 2009), the cultural imprints of society (Astrachan, 1988), their embeddedness in wider social networks (Le Breton-Miller \& Miller, 2009), and their integration into institutional and political frameworks (Berrone, Cruz, Gomez-Mejia, \& Larraza-Kintana, 2010). Although every economic entity is somehow situated or embedded in different contexts (Granovetter, 1985) and those different contexts (e.g., organisational, cultural, social, institutional) have been analysed by family business scholars in a variety of ways, the spatiality aspect of context has received little academic attention in this realm (with some exceptions, such as Seaman, 2012, 2013, 2015; Basco, 2015; Stough et al., 2015; Basco, Stough, \& Suwala, 2020; Basco \& Suwala, 2020).

On the other hand, in regional studies (including regional science, urban and regional economics, economic geography, urban and regional planning and management, etc.), research on firms has experienced a renaissance in the last 25 years (e.g., Dicken \& Malmberg, 2001; Taylor \& Asheim, 2001; Taylor \& Oinas, 2006). The origins of this interest can be traced back to Robert B. McNee's (1958) seminal contribution 'Functional Geography of the Firm'. The following years were characterised by studies on the increasingly global geography of large inter- and multinational conglomerates (e.g., in the petroleum industry) (Krumme, 1969; Taylor, 1975; Dicken, 1976). The crisis of the Fordist formation in the 1970s and 1980s brought research on firms and regional decline to the fore (Hayter \& Watts, 1983; Laulajainen \& Stafford, 1984; Malecki, 1985), while paving the way for the resurgence and re-examination of small and medium enterprises in (mature) industrial districts of the Third Italy (Becattini, 1978). Later, firms were seen as a forge of innovation situated in new industrial spaces and technology parks with an accompanied interest in regional entrepreneurship and a new wave of high-tech activities. In this vein, scholars from regional studies also focused on specific types of firms (e.g., new-born, small, medium, large, and foreign firms) when dismantling the role they play in regional and economic development (Scott, 1986; Giaoutzi, Nijkamp, \& Storey, 1988; Sternberg, 1989; Fritsch, 1992). Then, the network paradigm took over, which dealt with the increased complexities of horizontal and vertical (dis)integration and the rise of digital firms (Yeung, 2000; Taylor \& Oinas, 2006). However, the phenomenon of family firms has not been seriously considered by regional study scholars, who have mainly observed the family (business) as a supporting condition of spatial contexts with no systematic approach until recently (Stough et al., 2015; Suwala, 2019).

Considering the aforementioned evolution in each field of research, this chapter takes different theoretical perspectives and searches for a common 
fertile conceptual ground between family firm and regional studies. To address this aim, we first provide an overview of studies from the former, dealing with spatial entities, as well as investigations from the latter, dealing with family business issues. Second, we present two conceptual modelsthe spatial family management model (Suwala \& Oinas, 2012; Suwala, 2019) from regional studies and the regional familiness model (Basco, 2015) from family business studies - which are the seedbeds for that fertile ground between both disciplines. Finally, we juxtapose both fields according to different types of spatial entities.

\section{Searching for fertile ground between family business studies and regional studies}

\section{Family business scholars dealing with spatial entities}

Even though mainstream research in the field has focused on the internal aspects of the family-business relationship, family business studies explored topics related to space (context) relatively early in the discipline's formation. For instance, early studies tried to invoke location or spatial distribution as a determining factor when defining family firms. Westhead and Cowling (1998), in a bivariate analysis, found that family firms are over-represented in rural locations and under-represented in resource-rich core regions in the United Kingdom (Westhead \& Cowling, 1998, 54).

Probably, the first attempt to deal with spatial entities, or more precisely spatial factors, was Kahn and Henderson's (1992) work investigating family firms and locational factors. The general idea underlying this study is that family firms have to balance both the family and business perspectives in strategic decision-making, such as when choosing their location (see also Hollander \& Elman, 1988). In a sample comparing family firms and nonfamily firms, Kahn and Henderson (1992) found only mixed support for the assumption that family firms prefer soft locational factors (e.g., quality of life and amenities, among others) in relation to non-family firms, highlighting the importance of rational hard locational factors in firms' decision-making (e.g., proximity to markets and facility costs among others). However, they found that family firms are more concerned with spatial proximity to their residence than non-family firms (Kahn \& Henderson, 1992). In general, family ownership seems to affect business decisions; whether this influence is adverse or beneficial will require further investigation (Scranton, 1993; Getz \& Petersen, 2004; Ingstrup, Jensen, \& Lüthje, 2016). Today, this research stream mostly investigates locational factors for family businesses in specific countries (e.g., Heinemann et al., 2019).

Apart from family firms' locational preferences, some studies have focused on the spatial structure and distribution of family firms and their impact on local and regional economies (Pérez \& Raposo, 2007; Spiegel \& Block, 2011; Scholes, Wilson, Wright, \& Noke, 2012). Exploring West Germany at the district level (NUTS-3), Spiegel and Block (2011) emphasised that family 
firms tend to be located in rural areas in proximity to regional metropoles. They found that North Rhine-Westphalia and Baden-Württemberg (two economic powerhouses in Germany) have the highest densities of family firms, confirming the assumption that they are located in economically strong regions (Spiegel \& Block, 2011). Taking the spatial distribution of 245 large Spanish family firms into account, Pérez and Raposo (2007) confirmed the hypothesis that family firms are located in the most important economic centres (traditional industrial areas) with headquarters in Catalonia, Madrid, Aragon, the Basque Country, and Valencia.

The third and probably most popular research stream up to today focuses on family firms' internationalisation, which could be considered a spatial processes. Starting with Gallo and Sveen's (1991) seminal study on factors hindering and favouring this process, the topic of internationalisation has become popular among family business scholars. Most studies have focused on either searching for key determinants or ideal pathways (process view) to explain it (e.g., Gallo \& Pont, 1996; Okoroafo, 1999; Graves \& Thomas, 2008) or analysing the influence of family resources, ownership, heterogeneity, and networks (Calabrò, Campopiano, Basco, \& Pukall, 2017) (for a detailed literature overview, see Kontinen \& Ojala, 2010; Pukall \& Calabrò, 2014, and for a review of theoretical frameworks, see Kraus et al., 2016; Reuber, 2016; Arregle, Duran, Hitt, \& Van Essen, 2017) on family firms' internationalisation.

The fourth research stream, which is a bit far-flung, focuses on family firms across various spatial contexts. Studies on spatial contexts encompass different perspectives by considering emerging markets (Basco, 2018; Suwala, Kulke, \& Gade, 2018; Rienda, Claver, Quer, \& Andreu, 2019), transition economies (e.g., Donckels \& Lambrecht, 1999; Banalieva, Eddleston, \& Zellweger, 2014; Stangej \& Basco, 2017), home regions (Banalieva \& Eddleston, 2011; Pongelli, Calabrò, \& Basco, 2019), urban versus rural locations (Backman \& Palmberg, 2015; Baù et al., 2019), specific countries (e.g., Kowalewski, Talavera, \& Stetsyuk, 2010; Daszkiewicz \& Wach, 2014), and specific regions (e.g., Müller, Botero, Cruz, \& Subramanian, 2018). The main rationale behind these investigations is that context can be related to family firms' wellbeing, functional logic, and success factors. Context leads to idiosyncratic practices. Therefore, it is not surprising that family firms are often tied to a specific spatial entity, such as their home region (e.g., Hennart, Majocchi, \& Forlani, 2019). For example, Donckels and Lambrecht (1999) found that the re-emergence of family firms in East Central Europe in the 1990s was mostly driven by firms' implementation of crucial management functions and their growth aspirations. In other words, these studies account for spatial varieties of family firms.

The fifth research stream highlights the spatial scales of family firms, such as local (Seaman, McQuaid, \& Pearson, 2017; Baù et al., 2019), regional (Chang, Chrisman, Chua, \& Kellermanns, 2008; Bird \& Wennberg, 2014), 
and global (De Massis, Frattini, Majocchi, \& Piscitello, 2018). Most newer studies have considered these different scales not solely as passive surroundings but rather as active spatial frames that provide unique embeddings enabling family firms to thrive. The recursive relationship between family firms and location can have many dimensions: local embeddedness; family corporate local responsibility; family firm-led place leadership (Albers \& Suwala, 2020a-c; Graffenberger \& Görmar, 2020); family firm-led regional economic growth and development (Basco, 2015); and family firm-led local persistence, resilience, and sustainably (Brewton, Danes, Stafford, \& Haynes, 2010; Ljungkvist \& Boers, 2016). Therefore, local (i.e., socio-spatial) embeddedness is a particularly important feature of family firms (Basco, 2018; Selcuk \& Suwala, 2020). In this realm, Bird and Wennberg $(2014,424)$ conclude that 'family businesses are more embedded within the regional community than their non-family counterparts'.

The sixth research stream deals with family firms' spatial settings. This refers to the spatial configurations that make places unique. For instance, the territorial innovation models (i.e., industrial districts, local networks, clusters, or regional innovation systems) (e.g., Block \& Spiegel, 2013; Cucculelli \& Storai, 2015; Lopes, Branco, Parejo, \& Rangel, 2016; Basco \& Calabrò, 2016; Seaman et al., 2017; Konsti-Laakso et al., 2019; Amato, Basco, Backman, \& Lattanzi, 2020). All territorial innovation models 'emphasize the importance of spatial proximity ... in generating production, knowledge, learning processes and/or innovation in certain locales' (Brinkhoff, Suwala, \& Kulke, $2015,129)$. With regard to industrial districts in the Italian manufacturing industry, Cucculelli and Storai (2015) concluded that the family effect and the district effect both act as substitutes and complements depending on the size of Italian manufacturing firms. Block and Spiegel (2013) investigated the effect of family firms and regional innovation systems, finding evidence that the higher the density of family firms, the higher the level of innovation outputs, which in turn enhances regional patent outputs. Apart from that, Seaman et al. (2017) showed that family-owned firms make considerable contributions towards local economies through manifold linkages manifested via family, business, and friendship networks.

The seventh research stream comprises thoughts about spatial concepts. Seaman (2012 and 2013) developed an interesting framework of four types of spaces for business development that combines three types of inner space and one type of outer. Conceptual space refers to a cognitive superstructure that includes the idea of the family firm as a desirable activity as well as initial ideas supporting business development. Cultural space refers to the space created within the family by social and financial capital. Contingency space is about the help the family provides to the firm during the start-up phase, including both hands-on assistance and a pool of individuals with tacit knowledge and emotional commitment to the business. As a result of these different types of spaces, families and businesses create idiosyncratic 
knowledge that is deeply interwoven and mediated through networks in an additional space — called community space — and thus facilitates (regional) development.

Additionally, different topics related to spatial policies and planning have been investigated with less research intensity (Glassop \& Graves, 2010; Basco \& Bartkevičiūtè, 2016). Even though family firms play an important role in regional and national economies, studies on regional policy have generally only focused on policies aimed at supporting family business, such as tax benefits or advice about ownership and management succession (Basco \& Bartkevičiūtè, 2016). This poor state of scientific studies exists despite policymakers' knowledge of family firms' idiosyncratic needs and challenges in terms of intergenerational business transfer, financial obligations, business-family balance, lack of specific education, access to finance for growth, and ability to maintain a skilled workforce (Glassop \& Graves, 2010). Ricotta, Golikova, and Kuznetsov (2017) found no notable differences affecting the innovative performance of family firms versus non-family firms in seven European countries and Russia despite different development phases of the economy and institutional environments among countries (as a proxy for spatial policies). For South Asia, Samphantharak (2019) reported that ownership and control are concentrated among a handful of prominent families that have formed business groups. These family business groups maintain extensive connections with politicians and bureaucrats and therefore indirectly exert power over relevant local and regional policies in favour of family businesses (e.g., 'guanxi capitalism' and 'bamboo networks') (Samphantharak, 2019).

\section{Regional studies scholars dealing with family businesses}

Although regional studies scholars emphasised early on that the family is a crucial factor when an individual firm's locational choice is at stake (Townroe, 1969), the phenomenon of the family firm was mostly disconnected from spatial scales and from any internal and idiosyncratic spatialities (Taylor \& Asheim, 2001). Since space (and time) are abstract variables that dominate the discourse in regional studies, it is not surprising that the family has been a less important and often neglected dimension. The contributions of regional studies scholars in relation to family firms are scarce and fragmented in term of zeitgeist, research methods, theoretical concepts, and policy interventions.

The first research stream we can highlight, probably the strongest attempt to broach the subject of the family in regional studies, was the (re-)discovery of the Marshallian industrial districts (MIDs) - a particular spatial setting (Bagnasco, 1977; Becattini, 1978). Industrial districts are 'clusters of small family- and craft-based firms in the rural areas of the Third Italy ... with petit bourgeois traditions, community-wide social and economic rules, and municipal mercantilist traditions, which are historically sedimented 
in particular areas' (Trigilia, 1990, 199). These family firm-based spatial settings were viewed as a new regional remedy in the Fordist crisis of the 1970s and 1980s (Paci, 1980; Pyke, Becattini, \& Sengenberger, 1990). In this sense, the link between economic spaces and family firms emerges when one considers that 'the spatial integration of productive and reproductive spheres also permits artisans to rely on the casual labour of family members, particularly women and pensioner[s]' (Lazerson, 1990, 121). Family in business is the crucial argument for family-based spatial settings, with Marshallian theory initially being extended to analyse the successful performance of regionally concentrated systems of production based on family-owned and highly specialised small and medium-sized enterprises. Moreover, industrial districts orchestrate market mechanisms and social institutions, such as families, kinship networks, and local communities, capitalising on external economies of scale (Trigilia, 1986). However, the family as an important ingredient in spatial settings was picked up randomly in studies investigating the spatial organisation patterns of post-Fordist formation in relation to new business formation (Garofoli, 1994) and the advantages of small and medium-sized enterprises (Bryson, Wood, \& Keeble, 1993) due to cooperation, trust, and reciprocity among spatially proximate economic entities (Hansen, 1992).

Apart from the Italian industrial district, the Wenzhou model (Yeung, 2000; Wei et al., 2007) and the Gnösjo Spirit (Wigren, 2003) became popular research frameworks for exploring family firm-driven regional development, wherein business, family, and spatial context were heavily intertwined. In these frameworks, family firms or kinship ties serve as the 'glue' for socio-spatial proximity, holding together spatial arrangements and localized social relationships in socalled territorial innovation models (innovative milieus, clusters, regional innovation systems, and new industrial spaces) (Sforzi, 1989; Pypłacz, 2013; Brinkhoff et al., 2015). Therefore, in regional studies, the firm is frequently considered 'an organisational unit bringing together diverse social relations in which actors are embedded ... [and] these relationships may be inter-personal relationships, family linkages or simply social ties' (Yeung, 2000, 311). In other words, the firm and its (family) management orchestrate spatial locations and networks, all of which are stabilised by family ties (Suwala \& Oinas, 2012; Suwala, 2019).

A second research stream considers the family and family firms as (un-)favourable spatial factors or structures in local decisions. While Malecki (2000) subsumed the family as a soft factor in regional science, Zhou (1996) and Suwala and Kitzmann (2019) emphasised the benefits of spatially-concentrated ethnic and migrant family firms. Moreover, research has shown that founders/owners tend to locate near their families and friends in general (Schamp, 2005; Stam, 2007; Martyniuk \& Gierusz, 2016) as these soft locational factors are important for firm performance and survival (Martyniuk-Peczek, Martyniuk, Gierusz, \& Peczek, 2017; Suwala, 2019). Based on a study of 251 Polish firms, Martyniuk and Gierusz (2016) confirmed that in the case of family business, when deciding on the location for their business activity, the majority of owners choose a location near their home/residence. 
The increased availability and accessibility of family business-specific and regionally dis-aggregated data has enabled new research on the spatial structures of family-based economic activities and their recursive relationship with the context (e.g., Adjei et al., 2016; Berlemann \& Jahn, 2016; Majocchi, D’Angelo, Forlani, \& Buck, 2018; Amato, 2019). Amato (2019) provided a fine-grained look into the generally positive association between family-managed firms and employment growth within a large panel dataset of Spanish manufacturing firms during the economic recession between 2007 and 2008. He concluded that when location is considered, municipality size positively affects employment growth within family-managed firms. Moreover, the results reveal that during the economic crisis, the reduction in employment level was less pronounced for family-managed firms located in small municipalities due to their stronger socioeconomic ties than for those in larger urban settings (Amato, 2019). The rationale here is that spatial structures make a difference for family firms.

A third research stream takes the availability of new data to explore the phenomenon of family firm at different spatial scales, ranging from local (e.g., Yanagisako, 2002; Baschieri, Carosi, \& Mengoli, 2017) to global (e.g., Yeung \& Soh, 2000; Majocchi et al., 2018). Interestingly, the widely acknowledged local home bias of family firms could not be confirmed in the study by Baschieri et al. (2017). Using a dataset of Italian firms (half of them family firms) over the 1999-2011 period, they concluded that local home bias was not a common phenomenon among the entire sample and mainly occurred in family firms in which the founder led the business. Local home bias did not occur in non-family firms and in family firms in which the owner had acquired control through a market transaction. Moreover, the results suggest that locally committed family firms elicit investor preference for local stocks and, in doing so, exploit local clientele to lower the cost of funding. This means that family firms' social contributions to their local communities may have an opportunistic effect (Baschieri et al., 2017).

A fourth research stream links family firms to spatial processes such as regional learning, innovation, and internationalisation (Yeung, 2000; Wei et al., 2007; Berlemann \& Jahn, 2016; Adjei, Eriksson, Lindgren, \& Holm, 2019; Amato, 2019). This stream mostly investigates different dimensions of social capital and proximities that influence firm performance and thus regional prosperity (Karakayaci, 2013; Pucci, Brumana, Minola, \& Zanni, 2017; Suwala \& Micek, 2018). For example, studies have shown that the family and different forms of entrepreneurial family relationships can be considered sources of effective learning or skills and thereby contribute to differences in firm performance across regions (Adjei et al., 2016, 2019). With regard to innovation, for Italy, Pini (2019) showcased that while external management significantly affects firms' propensity for innovation in the more advanced area (centre-north), in the less developed area (south), it requires an additional simultaneous investment in research and development to drive firms' innovation in family management. However, it is unclear whether a strong presence of family firms in certain spatial settings always 
leads to prosperity. Schamp (2005) concluded that the lack of flexibility in regions dominated by traditional family branches, which often have a high density of family firms, might result in regional cognitive lock-in, regional sclerosis, and/or regional decline.

A fifth research stream comprises spatial policy and planning approaches, where family firms have been considered complementary additional actors in the development of local and regional economies (Albers \& Suwala, 2018, 2020a-c; Graffenberger \& Görmar, 2020). Albers and Suwala (2018 and 2020) differentiated between different intensities of so-called 'corporate spatial responsibility' - a spatial extension of the traditional concept of corporate social responsibility - and the impact on regional development. As shown in some cases, family firms' local commitment became so intensive that they coined these family firm initiatives as family firm-led local and regional economic development. In these cases, family firms took over former sovereign and administrative districts as well as county and state tasks necessary for local and regional governance and exerted genuine place leadership through holistic local future plans and master plan initiatives (Albers \& Suwala, 2018, 2020c; Suwala et al., 2018).

\section{Spatial familiness and family spatialities}

The contemporary re-discovery of space in family business research studies and families within territories have connected family business studies with regional studies. Not until recently did both these research streams start the cross-fertilisation process. While scholars like Basco (2015) and Stough et al. (2015) from family business studies raised the question of whether the mere presence of family firms is good or bad for regional economic development, Suwala and Oinas (2012) from the regional studies field almost simultaneously examined the micro-foundations of the spatial management of (family) firms.

To explore each of the aforementioned streams, we first present the conceptual model of spatial family management, which aims to interpret how different spaces affect family management (Suwala \& Oinas, 2012). Second, we re-visit the regional familiness model (Basco, 2015), which aims to capture family firms' embeddedness in social, economic, and productive structures within the spatial context to explain family firms' role in regional development. For both approaches, we shed light on the spatial entities we discussed in the previous sections-namely, factors and structures, processes, contexts, scales, settings, policies, and concepts.

\section{Spatial family management model}

Despite being a central topic in regional studies, neither the firm nor the manager have been properly acknowledged, due to the rather macro perspective used to develop models of spatial economies (e.g., von Thünen, Weber, Christaller, Lösch, Isard). Moreover, these models assume a passive interpretation of the individual as homo economicus (Suwala, 2020). Despite 
novel and promising developments in the field, the (family) manager is still considered rather lonesome or, more precisely, a fragmented maverick (Suwala \& Schlunze, 2019). The management geography ${ }^{1}$ research stream (Schlunze, Baber, \& Agola, 2012; Suwala \& Oinas, 2012) attempts to explain managerial agency across and within spaces when businesses have to decide on appropriate locations, local or international operations, strategic relationships with suppliers and customers, and internal and external images. In other words, this research stream aims to analyse the management of economic, social, and cognitive spatial domains in multi-scalar configurations and their influence on corporate performance through concentration, interaction, and perception (Suwala \& Oinas, 2012). Family managers have to address three spatialities-economic, social, and cognitive spacesspatialy-influenced self-reinforcing (dis-) and each of them can be seen as a continuum between different types of economies versus diseconomies of scale i.e., spatialy-influenced self-reinforcing (dis-) economies (Suwala, 2014).

First, the economic space can be thought of as a location. Space retains economic meaning as a location due to the simple fact that transport and transaction expenses occur over distance; hence, location is relative (against other locations), and spatial costs (e.g., transaction and transportation costs) can be calculated (Suwala, 2020). Within this domain, the family manager has to address different problems related to location, such as the firm's locational strategy, the optimal spatial choice regarding locational factors, and internationalisation-related decision making (e.g., liabilities of foreignness) (Suwala \& Kulke, 2017). Managerial tasks have to optimise self-reinforcing
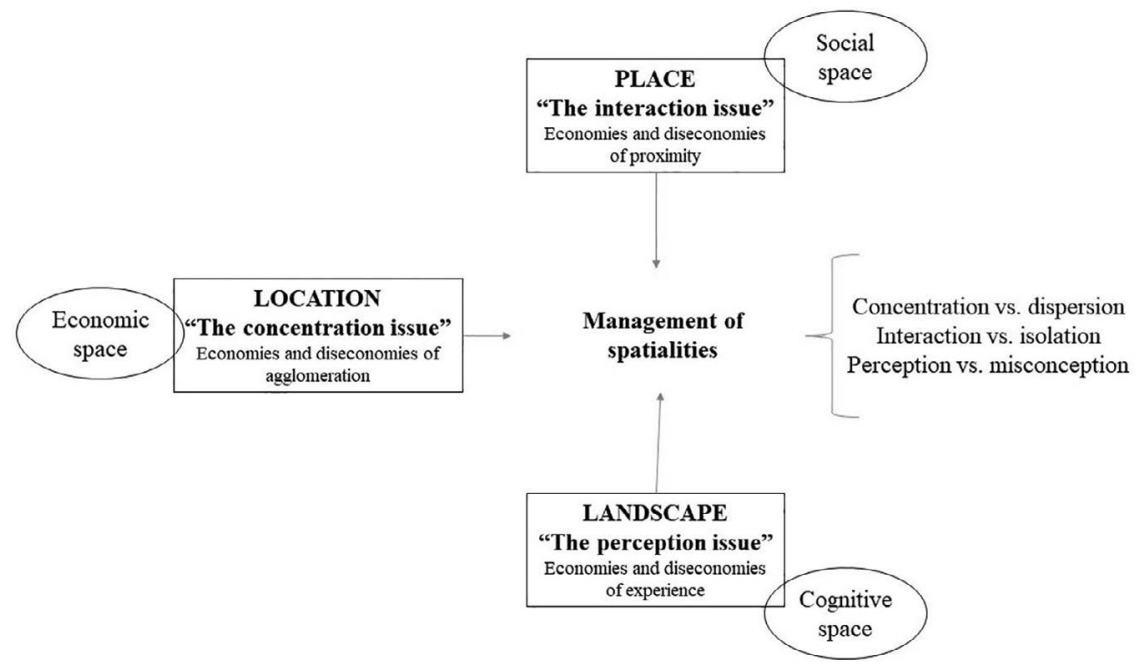

Figure 1.1 Spatial family management model (adopted and refined further from Suwala and Oinas [2012], Suwala [2019]). 
spatial mechanisms arising from agglomeration economies that are internal (e.g., economies of scale and scope) and external (e.g., localisation and urbanisation economies) to the firm. Here, spatial factors (importance of locational factors), spatial structures (relative location of the business), and partly spatial processes (expansion and internationalisation of the firm) are important. Managers have to optimally balance the concentration and dispersion of economic activities within space (Suwala, 2019).

Second, the social space is perceived as a place. A place is constructed through social ego-centric relationships between individuals; hence, it is relational. In other words, 'social space involves the network of functional relationships and social interactions' (Trip \& Romein, 2010, 5). Places are about context, and they can only be understood through actors' social and relational embeddedness (Selcuk \& Suwala, 2020). Within this domain, the family manager has to balance family relationships, internal and external firm ties (suppliers, customers, etc.), and friendship networks (Suwala, 2019) to provide solutions to the fundamental problem of coordinating relationships between economic actors. These relationships are characterised by different dimensions of proximities (e.g., spatial, cognitive, organisational, institutional, and cultural) (Knoben \& Oerlemans, 2006). Proximities may become proximity economies when fuelled by power, trust, and reciprocity, resulting in place-based knowledge and learning processes (by means of face-to-face meetings) (Storper \& Venables, 2004). However, not only is being there (spatial proximity, physical presence) important but so is being aware (cognitive proximity) (Grabher et al., 2018). Managers have to orchestrate the firm's networks its interaction and isolation while being situated in particular spatial contexts and spatial settings (e.g., industrial districts, migrant communities) (Suwala, 2019).

Finally, the cognitive space can be visualised as a landscape. Landscapes are the result of individuals' topo-centric relationships with space. Individuals (e.g., employees) are bound together not only by (ego-)relationships among themselves (relational view) but also through topical-relationships directly with space (Suwala, 2020). The result is a topical field in which individuals collectively share similar cognitive images, spatial mindsets, and particular atmospheres without necessarily knowing each other personally (Brinkhoff et al., 2015). Within this domain, the family manager lays out firm ethics or a family charter in order to establish a long-lasting firm culture that is reinforced by manifold images related to the family name, house symbols, and logos and in which the environment or workplace design plays a crucial role. This cognitive space is about a 'stockpile of knowledge, traditions, memories and images' (Scott, 2010, 123), which helps create a (mutual) atmosphere to stimulate particular perceptions and holistic experiences. The cognitive space as landscape may result in experience economies (e.g., entertainment, educational, aesthetic, and escapist experiences) (Suwala, 2014) depending on the intensity of attention and the memorability of extraordinary events and may arise from overlapping perceptions among individuals (Lange, Power, \& Suwala, 2014; Pfeufer \& Suwala, 2020). Therefore, 
managers have to set up and balance between perceptions and misconceptions of economic actors' experiences with family firms creating a certain spatial context - spatial processes like local learning, creativity, and innovation.

Extending these ideas from management geography to the family business field, managerial decisions in the context of family firms have to balance three different spatialities - economic, social, and cognitive spaces-and each can be interpreted as a continuum between different types of (dis-) economies arising from concentration/dispersion, interaction/isolation, and perception/misconception. Each of these spatialities comprises different managerial roles, such as the concentration role as a locational explorer (relative view, economic space, concentration), the interactional role as an embedded gatekeeper (relational view, social space, interaction), and the informational role as an experienced preceptor (topic view, cognitive space, perception) (Figure 1.1).

\section{Regional familiness model}

Since family involvement in the firm affects the way an organisation is owned, governed, and managed, consequently, it is a source of heterogeneity among family firms and between them and non-family firms. The microfoundations of the spatial family management model should be linked to the meso- and macro-foundations in order to theoretically and empirically interpret the effect of family firms at different spatial scales (e.g., local or regional). In this sense, the regional familiness model aims to connect the meso- and macro-foundations of family firms in regional studies.

Following Basco (2015), we define regional familiness as the consequences of family businesses' embeddedness in the spatial context that alter regional or spatial factors (i.e., tangible and intangible factors) and regional or spatial processes (e.g., spill-overs, information exchange, learning processes, social interactions, competition dynamics, and institutional dynamics) through proximity dimensions (i.e., relational, institutional, organisational, social, and cognitive proximities). In this sense, the family firm is not only an important actor due to its mere presence but also a driver of heterogeneity for regional factors and processes and their associated proximity dimensions.

The first connection that the regional familiness model proposes is the effect of family firms on regional factors (spatial factors). Regional or spatial factors are the aggregate resources (tangible or intangible, endogenous or exogenous) in an adopted spatial entity. They include not only traditional neoclassical resources related to capital and labour but also human factors (knowledge embedded in the labour force), social factors (networks and access to networks through which information flows), and entrepreneurial factors (ability and willingness to discover and exploit opportunities). The distinctive characteristics of family involvement in economic activities develop and create aggregate factors that, because of their endogenous 
characteristics, represent basic elements that may determine the quantity, quality, and pace of economic and social development. It is important to recognise that the aggregate effect of family firm activities could alter existing regional factors, imprinting them with specific properties, such as patient capital, local re-investment, and long-term commitment, but could also create additional unique and difficult-to-imitate regional factors, such as labour commitment, collective knowledge transfer across generations, stock of kinship and social relationships, and collective entrepreneurial spirit (see the literature on territorial innovation models_-Brinkhoff et al., 2015).

However, understanding the effect of family firms on regional factors is necessary to unpack family firms' connection to the meso-level; regional factors need regional processes that are responsible for exploiting and allocating them. The main regional or spatial processes include spillovers, information exchange, learning processes, social interactions, competitive dynamics, and institutional dynamics. The quality of regional processes can accelerate or slow the productivity of regional factors and can thus have consequences for regional economic and social development. By recognising the existence of regional processes, it is possible to move the concept of space from an absolute and relative perspective to a relational perspective.

The efficient functioning of regional processes lies on the dimension of proximity. Proximity refers to the state, quality, sense, or fact of being near or next to in space, time, or relationship (Torre \& Wallet, 2014; Basco, 2015). However, just 'being there' is not sufficient for regional processes to function effectively. According to Boschma (2005), proximity is more than simple geographical proximity related to the physical distance between economic actors and between economic actors and regional factors. The concept of proximity has different dimensions. Cognitive proximity refers to 'the similarity of the subjective mental framework of actors and the tacit and codified knowledge owned by actors' (Westlund \& Adam, 2010, 112). Social proximity can be defined as the socially embedded relationships among agents based on trust derived from friendship, kinship, and experience (Brinkhoff et al., 2012). Finally, while organisational proximity refers to the individual relationships within the boundaries of an organisation itself and the relationships among organisations, institutional proximity is the general macro-level (political) framework.

Because family businesses are locally embedded and have historical roots in certain places, the regional familiness model proposes that the thickness and quality of proximity - in other words, the spatial context-are affected by the aggregate effect of family businesses. For instance, family firms generally intend to stay where they dwell (belong) even during difficult times like crises (Zhou, He, \& Wang, 2017). In this sense, family firms stabilise geographical proximity and therefore spatial structures across generations. The most promising and necessary aggregate effect of family firms is on cognitive and social proximity due to the intrinsic relationship between the family, the firm, and the local community (see already Astrachan, 
1988; Brinkhoff et al., 2012; Seaman et al., 2017). This relationship is pronounced in family firms since they are active actors in the regional socialisation process, in which economic, social, and emotional connections are not only generated between the family and the firm but also extended to the rest of the local community, creating a 'local atmosphere' (cf. original Marshallian ideas, Marshall, 1890, 198). Additionally, the kinship and friendship relationships within and beyond firm boundaries contribute to establishing a particular trust-based society (see also Paci, 1980). In this sense, the organisational nature of family firms stimulates organisational proximity by developing communication channels among firms (within and outside the region) and by establishing cooperation and competition. Finally, to a certain extent, family firms are responsible for developing institutional proximity - that is, the implicit and explicit values, cultural norms, ethical principles, and formal rules that frame local and regional economic activities.

In sum, the regional familiness model is a box of theoretical tools for analysing and interpreting the role family firms can play in regional development. It goes beyond the simple statement that the importance of family firms stems from the fact that the family business is the most common form of organisation and unpacks the meaning of their presence in economic space. Moreover, the model links spatial factors, spatial contexts, and spatial processes (consequences) and enables researchers to operate across various spatial scales (from meso- to macro-foundations) (see Figure 1.2).
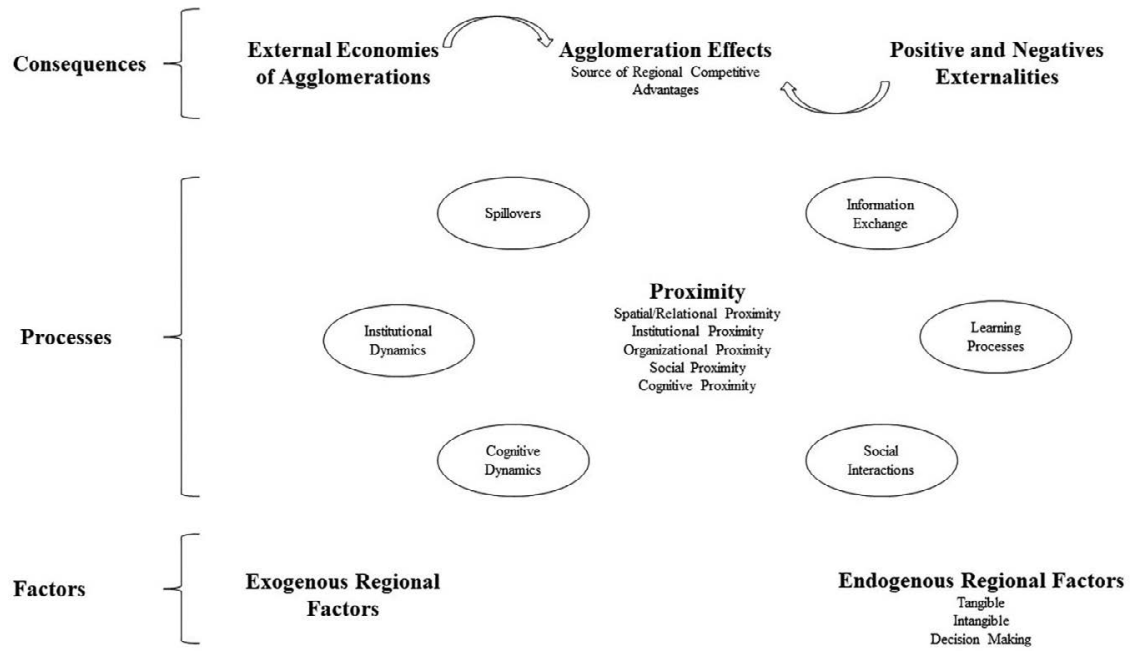

Figure 1.2 Regional familiness model (Basco, 2015). 


\section{Concluding remarks for fertile ground between family business studies and regional studies}

The spatial family management and regional familiness models can be combined to create a big picture that links all spatial scales (micro-, meso-, and macro-levels of analysis) and connects family business studies and regional studies. While the spatial family management model incorporates spatialities into family management decision making (family spatialities), the regional familiness model unpacks the role family firms play in regional economic and social development. What a combined model might look like is subject to further research in the near future (see also Basco \& Suwala, 2020). Table 1.1 summarises the main outcomes of the stock-taking studies in both disciplines and their relationships with the analysed spatial entitiesfactors, structures, processes, contexts, scales, settings, policies, and concepts.

Table 1.1 Key findings linking the fields of family business studies and regional studies

\begin{tabular}{|c|c|c|}
\hline & Family business studies & Regional studies \\
\hline $\begin{array}{l}\text { Spatial } \\
\text { factors }\end{array}$ & $\begin{array}{l}\text { Family firm founders choose } \\
\text { locations closer in proximity } \\
\text { to their residences than non- } \\
\text { family firm owners (Kahn \& } \\
\text { Henderson, 1992). }\end{array}$ & $\begin{array}{l}\text { Family firm owners tend to } \\
\text { locate near their families } \\
\text { and friends (Schamp, 2005; } \\
\text { Martyniuk \& Gierusz, 2016) } \\
\text { and favour soft locational } \\
\text { factors (Martyniuk-Peczek } \\
\text { et al., 2017; Suwala, 2019). }\end{array}$ \\
\hline $\begin{array}{l}\text { Spatial } \\
\text { structures }\end{array}$ & $\begin{array}{l}\text { Family firms are located in } \\
\text { rural and economically strong } \\
\text { regions (Pérez \& Raposo, } \\
\text { 2007; Spiegel \& Block, 2011). }\end{array}$ & $\begin{array}{l}\text { Family firms and specific } \\
\text { business functions are located } \\
\text { inside founding regions (Röhl, } \\
\text { 2008; Ermann, Lang, \& } \\
\text { Megerle, 2011: Mahr, 2017). }\end{array}$ \\
\hline $\begin{array}{l}\text { Spatial } \\
\text { scales }\end{array}$ & $\begin{array}{l}\text { Spatial scales serve as active } \\
\text { frames: local (Seaman } \\
\text { et al., 2017; Amato et al. 2020), } \\
\text { regional (Chang et al., 2008; } \\
\text { Bird \& Wennberg, 2014), global } \\
\text { (De Massis et al., 2018), and } \\
\text { home region (Banalieva \& } \\
\text { Eddleston, 2011). }\end{array}$ & $\begin{array}{l}\text { There is mixed evidence } \\
\text { regarding family firms' local } \\
\text { (e.g., Yanagisako, 2002) } \\
\text { and global structures (e.g., } \\
\text { Yeung \& Soh, 2000; Majocchi } \\
\text { et al., 2018). The widely } \\
\text { acknowledged home bias of } \\
\text { family firms loses significance } \\
\text { (Baschieri et al., 2017). }\end{array}$ \\
\hline $\begin{array}{l}\text { Spatial } \\
\text { contexts }\end{array}$ & $\begin{array}{l}\text { Spatial context can be related } \\
\text { to family firms' well-being, } \\
\text { functional logic, and } \\
\text { success factors (Backman \& } \\
\text { Palmberg, 2015; Basco, 2018; } \\
\text { Baù et al., 2019). }\end{array}$ & $\begin{array}{l}\text { Spatial context is seen as } \\
\text { socio-spatial embeddedness } \\
\text { interwoven in personal } \\
\text { networks (Mahr, 2017; } \\
\text { Selcuk \& Suwala, 2020). }\end{array}$ \\
\hline
\end{tabular}


Table 1.1 Continued

\begin{tabular}{|c|c|c|}
\hline & Family business studies & Regional studies \\
\hline $\begin{array}{l}\text { Spatial } \\
\text { settings }\end{array}$ & $\begin{array}{l}\text { There is mixed evidence for the } \\
\text { 'family effect' and the 'spatial } \\
\text { setting effect' in networks, } \\
\text { districts, and clusters } \\
\text { (Cucculelli \& Storai, 2015; } \\
\text { Basco \& Calabrò, 2016; Lopes } \\
\text { et al., 2016; Seaman } \\
\text { et al., 2017). }\end{array}$ & $\begin{array}{l}\text { Family firms and family } \\
\text { ties serve as the 'glue' for } \\
\text { socio-spatial proximity in } \\
\text { territorial innovation models } \\
\text { (Bagnasco, 1977; Yeung, } \\
\text { 2000; Wigren, 2003). }\end{array}$ \\
\hline $\begin{array}{l}\text { Spatial } \\
\text { processes }\end{array}$ & $\begin{array}{l}\text { There is mixed evidence } \\
\text { regarding the pathways family } \\
\text { firms' internationalisation } \\
\text { (Gallo \& Sveen, 1991; } \\
\text { Graves \& Thomas, 2008; } \\
\text { Calabrò et al., 2017; Amato, } \\
\text { Basco, Gómez-Ansón, \& } \\
\text { Lattanzi, 2020). }\end{array}$ & $\begin{array}{l}\text { There is mixed evidence } \\
\text { regarding family firms' } \\
\text { regional learning, } \\
\text { innovation, and } \\
\text { internationalisation (Wei } \\
\text { et al., 2007; Berlemann \& } \\
\text { Jahn, 2016; Adjei et al., 2019; } \\
\text { Amato, 2019; Felzensztein, } \\
\text { Deans, \& Dana, 2019; Lenz, } \\
\text { 2020). }\end{array}$ \\
\hline $\begin{array}{l}\text { Spatial } \\
\text { policies }\end{array}$ & $\begin{array}{l}\text { Family firms are under- } \\
\text { represented in regional } \\
\text { policies based on their } \\
\text { importance in economies } \\
\text { (Glassop \& Graves, 2010; } \\
\text { Basco \&Bartkevičiūte, 2016) } \\
\text { and their commitment } \\
\text { towards their home regions } \\
\text { (Kim, Haider, Wu, \& Dou, } \\
\text { forthcoming). }\end{array}$ & $\begin{array}{l}\text { Family firms have corporate } \\
\text { spatial responsibilities } \\
\text { related to educational, social, } \\
\text { and cultural issues (Jahn, } \\
\text { 2015; Albers \& Suwala, 2018; } \\
\text { Graffenberger \& Görmar, } \\
\text { 2020). }\end{array}$ \\
\hline $\begin{array}{l}\text { Spatial } \\
\text { concepts }\end{array}$ & $\begin{array}{l}\text { The conceptual space, cultural } \\
\text { space, community space, and } \\
\text { contingency space in family } \\
\text { firms are linked by networks } \\
\text { (Seaman, 2012, 2013, 2015). }\end{array}$ & $\begin{array}{l}\text { The existing research is } \\
\text { focusing on management of } \\
\text { the relative space, relational } \\
\text { space, and topical space in } \\
\text { family firms (Suwala, 2014, } \\
\text { 2020; Amato, 2019). }\end{array}$ \\
\hline $\begin{array}{c}\text { Multiple } \\
\text { spatial } \\
\text { entities }\end{array}$ & $\begin{array}{l}\text { The regional familiness model } \\
\text { explains the spatial factors, } \\
\text { contexts, and processes } \\
\text { (consequences) necessary to } \\
\text { enhance regional development } \\
\text { across different spatial scales } \\
\text { (Basco, 2015). }\end{array}$ & $\begin{array}{l}\text { The spatial family management } \\
\text { model explains multi- } \\
\text { spatial coordination tasks } \\
\text { incorporating spatial factors, } \\
\text { structures, contexts, settings, } \\
\text { and processes in decision } \\
\text { making (Suwala \& Oinas, } \\
\text { 2012; Suwala, 2019). }\end{array}$ \\
\hline
\end{tabular}

Concerning the research on spatial factors, we see a great deal of coherence in the results between both disciplines. The main idea is that family firm owners tend to locate near their families and friends and favour soft locational factors in comparison to non-family firm owners, who tend to make locational decisions based on rational cost-benefit considerations. In addition, family business research reveals the complicated relationship 
between the family's perspective and the business's perspective in locational choices. With regard to research on spatial structures and distribution, there is also an overlap between both streams. Family firms and their accompanying business functions are generally located inside founding regions, which indicates the spatial persistence of family firms. Moreover, family firms often provide both stability and breeding grounds for prosperous economic and social development. All of this happens not only in urban centres but also in rural areas in proximity to metropoles and outside of high-tech agglomerations (e.g., Germany's so-called 'hidden champion' firms). Furthermore, spatial scales are perceived as active surroundings in both disciplines rather than passive frames. Although unlimited in variety depending on the research interest at hand, home region (i.e., local region) bias still dominates the research, albeit with declining intensity. Spatial contexts still act as a lens to investigate family firms' wellbeing, functional logic, and success factors. This selection mechanism makes spaces and family firm practices unique. There is no 'one location fits all' approach, as both disciplines agree, because family firms, their locational imprints, their people, their practices, and their images are embedded in particular spaces. Here, research interests in both disciplines differ. Whereas regional studies scholars consider family firms and family ties the 'glue' necessary for socio-spatial proximity in territorial innovation models, there is mixed evidence within family business studies concerning the 'family effect' and the 'spatial settings effect' in networks, districts, and clusters.

There are also pertinent research approaches with regard to spatial processes. Whereas family business scholars mostly deal with the capabilities and pathways necessary for family firms to internationalise, regional studies scholars focus on regional learning and innovation processes. Research on spatial policies and planning measures is predominantly in the early stages in both disciplines, with various approaches treating family firms as both targets and initiators of policy interventions. In terms of spatial concepts, research has focused on both internal and external aspects: 'spaces of familiness' and 'family spatialities'.

Finally, the two presented models bridge multiple spatial entities: the regional familiness model, which outlines the spatial factors, contexts, and processes (consequences) necessary to enhance regional development by family firms across different spatial scales, and the spatial family management model, which suggests multi-spatial coordination tasks incorporating spatial factors, structures, contexts, settings, and processes into family firm managers' decision processes. Both models complement each other quite well since the latter describes the micro-foundations of managerial decision making that can be scaled upward through aggregated views by the former. Both research streams have overlaps but also idiosyncrasies originating from their fields. Therefore, we call for more interdisciplinary work to address research gaps and exchange insights on theoretical, empirical, and practical grounds to better investigate the phenomena of 'spatial familiness' and 'family spatialities'. 


\section{Note}

1 Sometimes also called 'managerial geography' (Laulajainen, 1998) or 'economic geographies of management' (Jones, 2016).

\section{References}

Adjei, E. K., Eriksson, R. H., \& Lindgren, U. (2016). Social proximity and firm performance: The importance of family member ties in workplaces. Regional Studies, Regional Science, 3(1), 304-320.

Adjei, E. K., Eriksson, R. H., Lindgren, U., \& Holm, E. (2019). Familial relationships and firm performance: The impact of entrepreneurial family relationships. Entrepreneurship \& Regional Development, 31(5-6), 357-377.

Albers, H.-H., \& Suwala, L. (2018). Unternehmensengagement als Standortfaktor mit der Wirtschaft attraktive (Klein-)Städte schaffen. Informationen zur Raumentwicklung, 6, 50-57.

Albers, H.-H., \& Suwala, L. (2020a). Place leadership and corporate spatial responsibilities. In M. Sotarauta \& A. Beer (Eds.), Handbook on City and Regional Leadership. Cheltenham: Edward Elgar Publishing.

Albers, H.-H., \& Suwala, L. (2020b). Family firms and corporate spatial responsibilities in Germany - implication on urban and regional planning and management. In R. Basco, R. Stough, \& L. Suwala (Eds.), Family Business and Regional Development. London: Routledge.

Albers, H.-H., \& Suwala, L. (2020c). Räumliches Unternehmensengagement (Corporate spatial responsibility) und Ortsführung (Place leadership) in Kleinstädten. Perspektiven für eine neue Ortsführung? Eine Zusammenführung von zwei Diskursen. In S. Döringer \& J. Eder (Eds.), Schlüsselakteure der Regionalentwicklung: Welche Perspektiven bietet Entrepreneurship für ländliche Räume? (pp. 63-84). Wien: ISR Forschungsbericht. Band 51.

Amato, S. (2019). Family Firms and Regional Economics: Current Debate and New Empirical Evidence (Unpublished doctoral dissertation). University of Pisa, Pisa, Italy.

Amato, S., Basco, R., Backman, M., \& Lattanzi, N. (2020). Family-managed firms and local export spillovers: Evidence from Spanish manufacturing firms. European Planning Studies, Forthcoming.

Amato, S., Basco, R., Gómez-Ansón, S., \& Lattanzi, N. (2020). Family-managed firms and employment growth during an economic downturn: Does their location matter? Baltic Journal of Management, 15(4), 607-630.

Arregle, J. L., Duran, P., Hitt, M. A., \& Van Essen, M. (2017). Why is family firms' internationalization unique? A meta-analysis. Entrepreneurship Theory and Practice, 41(5), 801-831.

Astrachan, J. H. (1988). Family firm and community culture. Family Business Review, 1(2), 165-189.

Backman, M., \& Palmberg, J. (2015). Contextualizing small family firms : How does the urban - rural context affect firm employment growth? Journal of Family Business Strategy, 6(4), 247-258.

Bagnasco, A. (1977). Tre Italie: La problematica territoriale dello sviluppo. Bologna: Il Mulino.

Banalieva, E. R., \& Eddleston, K. A. (2011). Home-region focus and performance of family firms: The role of family vs non-family leaders. Journal of International Business Studies, 42(8), 1060-1072. 
Banalieva, E. R., Eddleston, K., \& Zellweger, R. (2014). When do family firms have an advantage in transitioning economies? Toward a dynamic institution-based view. Strategic Management Journal, 36(9), 1358-1377.

Baschieri, G., Carosi, A., \& Mengoli, S. (2017). Family firm local involvement and the local home bias phenomenon. Long Range Planning, 50(1), 93-107.

Basco, R. (2013). The family's effect on family firm performance: A model testing the demographic and essence approaches. Journal of Family Business Strategy, 4(1), 42-66.

Basco, R. (2015). Family business and regional development-A theoretical model of regional familiness. Journal of Family Business Strategy, 6(4), 259-271.

Basco, R. (2018). Family business in emerging markets. In R. Grosse \& K. E. Meyer (Eds.), The Oxford Handbook of Management in Emerging Markets (pp. 527-545). Oxford: Oxford University Press.

Basco, R., \& Bartkevičiūtè, I. (2016). Is there any room form family business into European Union 2020 Strategy? Family business and regional public policy. Local Economy, 31(6), 709-732.

Basco, R., \& Calabrò, A. (2016). Open innovation search strategies in family and non-family SMEs: Evidence from a natural resource-based cluster in Chile. Academia Revista Latinoamericana de Administracion, 29(3), 279-302.

Basco, R., \& Suwala, L. (2020). Spatial familiness - A bridge between family business and economic geography. In A. Calabò (Ed.), A Research Agenda for Family Business: A Way Ahead for the Field, 185-202. Northampton, MA: Edward Elgar Cheltenham.

Basco R., Stough R., \& Suwala L. (2020). (Eds.), Family Business and Regional Development. London: Routledge.

Baù, M., Chirico, F., Pittino, D., Backman, M., \& Klaesson, J. (2019). Roots to grow: Family firms and local embeddedness in rural and urban contexts. Entrepreneurship Theory and Practice, 43(2), 360-365.

Becattini, G. (1978). The development of light industry in Tuscany: An interpretation. Economic Notes, 2(3), 107-123.

Berlemann, M., \& Jahn, V. (2016). Regional importance of mittelstand firms and innovation performance. Regional Studies, 50(11), 1819-1833.

Berrone, P., Cruz, C., Gomez-Mejia, L. R., \& Larraza-Kintana, M. (2010). Socioemotional wealth and corporate responses to institutional pressures: Do familycontrolled firms pollute less? Administrative Science Quarterly, 55(1), 82-113.

Bird, M., \& Wennberg, K. (2014). Regional influences on the prevalence of family versus non-family start-ups. Journal of Business Venturing, 29(3), 421-436.

Block, J. H., \& Spiegel, F. (2013). Family firm density and regional innovation output: An exploratory analysis. Journal of Family Business Strategy, 4(4), 270-280.

Boschma, R. A. 2005. "Proximity and Innovation: A Critical Assessment." Regional Studies 39(1): 61-74.

Brewton, K. E., Danes, S. M., Stafford, K., \& Haynes, G. W. (2010). Determinants of rural and urban family firm resilience. Journal of Family Business Strategy, 1(3), 155-166.

Brinkhoff, S., Suwla, L., \& Kulke, E. (2012). What do you offer?: Interlinkages of universities and hightechnology companies in science and technology parks in Berlin and Seville. In R. Capello, A. Olechnicka, \& G. Gorzelak (Eds.), Universities, Cities and Regions: Loci for Knowledge and Innovation Creation (pp. 121-146). London: Routledge. 
Brinkhoff, S., Suwala, L., \& Kulke, E. (2015). Managing innovation in 'localities of learning' in Berlin and Seville. In G. Micek (Ed.), Understanding Innovation in Emerging Economic Spaces (pp. 11-31). Ashgate: Farmham.

Bryson, J., Wood, P., \& Keeble, D. (1993). Business networks, small firm flexibility and regional development in UK business services. Entrepreneurship \& Regional Development, 5(3), 265-278.

Calabrò, A., Campopiano, G., Basco, R., \& Pukall, T. (2017). Governance structure and internationalization of family-controlled firms: The mediating role of international entrepreneurial orientation. European Management Journal, 35(2), 238-248.

Chang, E. P. C., Chrisman, J. J., Chua, J. H., \& Kellermanns, F. W. (2008). Regional economy as a determinant of the prevalence of family firms in the United States: A preliminary report. Entrepreneurship Theory and Practice, 32(3), 559-573.

Cucculelli, M., \& Storai, D. (2015). Family firms and industrial districts: Evidence from the Italian manufacturing industry. Journal of Family Business Strategy, 6(4), 234-246.

Daszkiewicz, N., \& Wach, K. (2014). Motives for going international and entry modes of family firms in Poland. Journal of Intercultural Management, 6(2), 5-18.

De Massis, A., Frattini, F., Majocchi, A., \& Piscitello, L. (2018). Family firms in the global economy: Toward a deeper understanding of internationalization determinants, processes, and outcomes. Global Strategy Journal, 8(1), 3-21.

Dicken, P. (1976). The multiplant business enterprise and geographical space: Some issues in the study of external control and regional development. Regional Studies, 10(4), 401-412.

Dicken, P., \& Malmberg, A. (2001). Firms in territories: A relational perspective. Economic Geography, 77(4), 345-363.

Discua Cruz, A., \& Basco, R. (2018). A family perspective on entrepreneurship. In N. Turcan \& R. Fraser (Eds.), A Handbook of Multidisciplinary Perspectives on Entrepreneurship (pp. 147-175). Switzerland: Palgrave Macmillan.

Donckels, R., \& Lambrecht, J. (1999). The re-emergence of family-based enterprises in East Central Europe: What can be learned from family business research in the western world? Family Business Review, 12(2), 171-188.

Ermann, U., Lang, T., \& Megerle, M. (2011). Weltmarktführer: Ein räumlicher und zeitlicher Überblick. Nationalatlas aktuell 5 (11.2011) 11 [30.11.2011]. Leipzig: Leibniz- Institut für Länderkunde (IfL).

Felzensztein, C., Deans, K. R., \& Dana, L. P. (2019). Small firms in regional clusters: Local networks and internationalization in the Southern Hemisphere. Journal of Small Business Management, 57(2), 496-516.

Fritsch, M. (1992). Regional differences in new firm formation: Evidence from West Germany. Regional Studies, 26(3), 233-241.

Gallo, M. A., \& Pont, C. G. (1996). Important factors in family business internationalization. Family Business Review, 9(1), 45-59.

Gallo, M. A., \& Sveen, J. (1991). Internationalizing the family business: Facilitating and restraining factors. Family Business Review, 4(2), 181-190.

Garofoli, G. (1994). New firm formation and regional development: The Italian case. Regional Studies, 28(4), 381-393.

Getz, D., \& Petersen, T. (2004). Identifying industry-specific barriers to inheritance in small family businesses. Family Business Review, 17(3), 259-276. 
Giaoutzi, M., Nijkamp, P., \& Storey, D. J. (1988). (Eds.), Small and Medium Size Enterprises and Regional Development. London: Routledge.

Glassop, L., \& Graves, C. (2010). Family-owned businesses: Perspectives on Australian policy. International Journal of Management Practice, 4(3), $293-305$.

Gomez-Mejia, L. R., Basco, R., Müller, C., \& Gonzalez, A. C. (2020). Family business and local development in Iberoamerica. Cross-Cultural Management Journal, 27(2), 121-136.

Grabher, G., Melchior, A., Schiemer, B., Schüßler, E., \& Sydow, J. (2018). From being there to being aware: Confronting geographical and sociological imaginations of copresence. Environment and Planning A: Economy and Space, 50(1), 245-255.

Graffenberger M., \& Görmar F. (2020), Family firms and corporate responsibility in peripheral regions. In R. Basco, R. Stough, \& L. Suwala (Eds.), Family Business and Regional Development. London: Routledge.

Granovetter, M. (1985). Economic action and social structure: The problem of embeddedness. American Journal of Sociology, 91(3), 481-510.

Graves, C., \& Thomas, J. (2008). Determinants of the internationalization pathways of family firms: An examination of family influence. Family Business Review, 21(2), 151-167.

Hansen, N. (1992). Competition, trust, and reciprocity in the development of innovative regional milieux. Papers in Regional Science, 71(2), 95-105.

Hayter, R., \& Watts, H. D. (1983). The geography of enterprise: A reappraisal. Progress in Human Geography, 7(2), 157-181.

Heinemann, F., Bräutigam, R., Bührle, A. T., Dutt, V., Fischer, L., \& Kraus, M. (2019). Länderindex Familienunternehmen. 7 Auflage. Mannnheim: ZEW.

Hennart, J. F., Majocchi, A., \& Forlani, E. (2019). The myth of the stay-at-home family firm: How family-managed SMEs can overcome their internationalization limitations. Journal of International Business Studies, 50(5), 758-782.

Hollander, B. S., \& Elman, N. S. (1988). Family-owned businesses: An emerging field of inquiry. Family Business Review, 1(2), 145-164.

Ingstrup, M. B., Jensen, K. W., \& Lüthje, T. (2016). Family firms and homeland production: Reasoning from agency theory and socio-emotional wealth theory. International Journal of Globalisation and Small Business, 8(4), 316-332.

Isard, W. (1999). Further thoughts on future directions for regional science: A response to Fujita's remarks on the general theory of location and space-economy. The Annals of Regional Science, 33(4), 383-388.

Jahn, V. (2015). The importance of Mittelstand firms for regional apprenticeship activity: Lessons for policy (No. 158). Diskussionspapier, Helmut-SchmidtUniversität, Fächergruppe Volkswirtschaftslehre.

James, A. E., Hadjielias, E., Guerrero, M., Discua Cruz, A., \& Basco, R. (2020). Entrepreneurial families in business acorss generations, context, and cultures. Journal of Family Business Management, forthcoming. doi:10.1108/CCSM-02-2020-223

Jones, A. (2016). Geographies of production III: Economic geographies of management and international business. Progress in Human Geography, 42(2), 275-285.

Kahn, J. A., \& Henderson, D. A. (1992). Location preferences of family firms: Strategic decision making or "home sweet home"? Family Business Review, 5(3), 271-282.

Karakayaci, O. (2013). Social capital and innovation in industrial clusters: An evidence from case of family and non-family firms in Turkey'. European Online Journal of Natural and Social Sciences, 2(3), 313-329. 
Kim, K., Haider, Z. A., Wu, Z., \& Dou, J. (2019). Corporate social performance of family firms: A place-based perspective in the context of layoffs. Journal of Business Ethics (forthcoming).

Knoben, J., \& Oerlemans, L. A. G. (2006). Proximity and inter-organizational collaboration: A literature review. International Journal of Management Reviews, 8(2), 71-89.

Konsti-Laakso, S., Heikkilä, J., Rautiainen, M., Rinkinen, S., \& Akhter, N. (2019). The contribution of family business groups to the local innovation environment. In M. Rautiainen, P. Rosa, T. Pihkala, M. J. Parada, A. D. Cruz (Eds.), The Family Business Group Phenomenon (pp. 287-314). Cham: Palgrave Macmillan.

Kontinen, T., \& Ojala, A. (2010). The internationalization of family businesses: A review of extant research. Journal of Family Business Strategy, 1(2), 97-107.

Kowalewski, O., Talavera, O., \& Stetsyuk, I. (2010). Influence of family involvement in management and ownership on firm performance: Evidence from Poland. Family Business Review, 23(1), 45-59.

Kraus, S., Mensching, H., Calabrò, A., Cheng, C. F., \& Filser, M. (2016). Family firm internationalization: A configurational approach. Journal of Business Research, 69(11), 5473-5478.

Krueger, N., Bogers, M., Labaki, R., \& Basco, R. (2020). Advancing family business science through context theorizing: The case of the Arab world. Journal of Family Business Strategy, forthcoming.

Krumme, G. (1969). Toward a geography of enterprise. Economic Geography, 45(1), $30-40$.

Lange, B., Power, D., \& Suwala, L. (2014). Geographies of field-configuring events. Zeitschrift für Wirtschaftsgeographie, 58(1), 187-201.

Laulajainen, R. (1998). What about managerial geography? GeoJournal, 44(1), 1-7.

Laulajainen, R., \& Stafford, H. A. (1984). Corporate Geography: Business Location Principles and Cases. Switzerland: Springer Science \& Business Media.

Lazerson, M. (1990). Subcontracting in the Modena knitwear industry. In F. Pyke, G. Becattini, \& W. Sengenberger (Eds.), Industrial Districts and Inter-firm Cooperation in Italy (pp. 108-133). Geneva: International Institute for Labour Studies.

Le Breton-Miller, I., \& Miller, D. (2009). Agency vs. stewardship in public family firms: A social embeddedness reconciliation. Entrepreneurship Theory and Practice, 33(6), 1169-1191.

Lenz, R. (2020). Family firms and their regional ties: A bond made for future? In R. Basco, R. Stough, L. Suwala (Eds.), Family Business and Regional Development. London: Routledge.

Ljungkvist, T., \& Boers, B. (2016). Structural crisis? Regional culture and resilience in family business-dominated regions in Sweden. Journal of Enterprising Communities: People and Places in the Global Economy, 10(4), 425-446.

Lopes, J. C., Branco, A., Parejo, F. M., \& Rangel, J. F. (2016). Determinants of success and failure in the internationalization of the cork business: A tale of two Iberian family firms. In M. H. Bilgin \& H. Danis (Eds.), Entrepreneurship, Business and Economics. Proceedings of the 15th Eurasia Business and Economics Society Conference (vol. 2, pp. 417-440). Switzerland: Springer International Publishing.

Mahr, A. L. (2017). Unternehmensnachfolge im Agribusiness-eine räumliche Perspektive. Vechta: Univeristy of Vechta.

Majocchi, A., D’Angelo, A., Forlani, E., \& Buck, T. (2018). Bifurcation bias and exporting: Can foreign work experience be an answer? Insight from European family SMEs. Journal of World Business, 53(2), 237-247. 
Malecki, E. J. (1985). Industrial location and corporate organization in high technology industries. Economic Geography, 61(4), 345-369.

Malecki, E. (2000). Soft variables in regional science. Review of Regional Studies, 30, 61-69.

Marshall, A. (1890). Principles of Economics. London: MacMillan.

Martyniuk, O., \& Gierusz, A. (2016). Location behavior of family firms evidence of Poland. Przedsiebiorczosc i Zarzadzanie, XVII (6/2), 283-295.

Martyniuk-Pęczek, J., Martyniuk, O., Gierusz, A., \& Pęczek, G. (2017). Determinants of SME location in a suburban area: Evidence from the Gdańsk-GdyniaSopot metropolitan area. Urbani Izziv, 28(1), 122-134.

McNee, R. B. (1958). Functional geography of the firm, with an illustrative case study from the petroleum industry. Economic Geography, 34(4), 321-337.

Müller, C. G., Botero, I. C., Cruz, A. D., \& Subramanian, R. (2018). Family Firms in Latin America. London. Routledge.

Okoroafo, S. C. (1999). Internationalization of Family Businesses: Evidence from Northwest Ohio, U.S.A. Family Business Review, 12(2), 147-158.

Paci, M. (1980). Struttura e funzioni della famiglia nello sviluppo industriale periferico. In M. Paci (Ed.), Famiglia e mercato del lavoro in un'economia periferica (pp. 9-70). Milan: Franco Angeli.

Pérez, P. F., \& Raposo, N. P. (2007). Bonsais in a wild forest? A historical interpretation of the longevity of large Spanish family firms. Revista de Historia EconómicaJournal of Iberian and Latin American Economic History, 25(3), 459-497.

Pfeufer, N., \& Suwala, L. (2020). Inwertsetzung von temporären Räumlichkeiten. Standortstrategien von Pop-up-Restaurants in Berlin. Spatial Research and Planning, 78(1), 71-87.

Pini, M. (2019). Family management and Industry 4.0: Different effects in different geographical areas? An analysis of the less developed regions in Italy. Journal of Entrepreneurship, Management and Innovation, 15(3), 73-102.

Pongelli, C., Calabrò, A., \& Basco, R. (2019). Family firms' international makeor-buy decisions: Captive offshoring, offshore outsourcing, and the role of home region focus. Journal of Business Research, 103, 596-606.

Pucci, T., Brumana, M., Minola, T., \& Zanni, L. (2017). Social capital and innovation in a life science cluster: The role of proximity and family involvement. The Journal of Technology Transfer, 45(1), 205-227.

Pukall, T., \& Calabrò, A. (2014). The internationalization of family firms: A critical review and integrative model. Family Business Review, 27(2), 103-125.

Pyke, F., Becattini, G., \& Sengenberger, W. (1990). (Eds.), Industrial districts and inter-firm co-operation in Italy. Genova: International Institute for Labour Studies. Retrieved from https://digitallibrary.un.org/record/63189? $1 \mathrm{n}=\mathrm{en}$

Pypłacz, P. (2013). Clusters as an opportunity for development of family enterprises. Polish Journal of Management Studies, 7, 212-220.

Reuber, A. R. (2016). An assemblage - theoretic perspective on the internationalization processes of family firms. Entrepreneurship Theory and Practice, 40(6), 1269-1286.

Ricotta, F., Golikova, V., \& Kuznetsov, B. (2017). Innovation performance of family firms in comparative perspective: The role of regional corruption in Europe and Russia. Retrieved from https://www.siecon.org/sites/siecon.org/files/oldfiles/ uploads/2017/04/Ricotta-1.pdf

Rienda, L., Claver, E., Quer, D., \& Andreu, R. (2019), Family businesses from emerging markets and choice of entry mode abroad: Insights from Indian firms. Asian Business \& Management, 18(1), 6-30. 
Röhl, K. H. (2008). Die Zukunft der Familienunternehmen in Deutschland: Potenziale und Risiken in der globalen Wirtschaft (No. 38). IW-Analysen.

Samphantharak, K. (2019). Family Business Groups and Economic Development in Southeast Asia. Available at SSRN 3328861.

Schamp, E. W. (2005). Decline of the district, renewal of firms: An evolutionary approach to footwear production in the Pirmasens area, Germany. Environment and Planning A, 37(4), 617-634.

Schlunze, R., Baber, W., \& Agola, N. (2012). (eds.), Spaces of International Economy and Management: Launching New Perspectives on Management and Geography. London: Palgrave Macmillan.

Scholes, L., Wilson, N., Wright, M., \& Noke, H. (2012). Listed family firms: Industrial and geographical context, governance and performance. Retrieved from https://papers.ssrn.com/sol3/papers.cfm?abstract_id=2002906.

Scott, A. (2010). Cultural economy and the creative field of the city. Geografiska Annaler: Series B, Human Geography, 92(2), 115-130.

Scott, J. (1986). Industrial organization and location: Division of labor, the firm, and spatial process. Economic Geography, 62(3), 215-231.

Scranton, P. (1993). Build a firm, start another: The Bromleys and family firm entrepreneurship in the Philadelphia region. Business History, 35(4), 115-151.

Seaman, C. (2012). The invisible bedrock: Four constructs of family business space. World Review of Entrepreneurship, Management and Sustainable Development, 8(3), 297-307.

Seaman, C. (2013). The invisible bedrock: Business families, networks and the creation of entrepreneurial space. World Review of Entrepreneurship, Management and Sustainable Development, 9(1), 101-113.

Seaman, C. (2015). Creating space for the business family: Networks, social capital \& family businesses in rural development. Journal of Family Business Management, 5(2), 182-191.

Seaman, C., McQuaid, R., \& Pearson, M. (2017). Social networking in family businesses in a local economy. Local Economy, 32(5), 451-466.

Selcuk, G., \& Suwala, L. (2020). Migrant Family entrepreneurship - Mixed and multiple embeddedness of transgenerational Turkish family entrepreneurs in Berlin. Journal of Family Business Management. Forthcoming.

Sforzi, F. (1989). The geography of industrial districts in Italy. In E. Goodman, et al. (Eds.), Small Firms and Industrial Districts in Italy (pp. 153-173). London: Routledge.

Spiegel, F., \& Block, J. H. (2011). Regionale bedeutung von familienunternehmen in Westdeutschland. Zeitschrift für KMU und Entrepreneurship, 61(1-2), 7-34.

Stam, E. (2007). Why butterflies don't leave: Locational behavior of entrepreneurial firms. Economic Geography, 83(1), 27-50.

Stangej, O., \& Basco, R. (2017). The entrepreneurial role of families in transitional economies. In A. Sauka \& A. Chepurenko (Eds.) Entrepreneurship in Transition Economies. Diversity, Trends, and Perspective (pp. 345-365). Berlin: Springer.

Steier, L. P., Chua, J. H., \& Chrisman, J. J. (2009). Embeddedness perspectives of economic action within family firms. Entrepreneurship Theory and Practice, 33(6), $1157-1167$.

Sternberg, R. (1989). Innovation centres and their importance for the growth of new technology-based firms: Experience gained from the Federal Republic of Germany. Technovation, 9(8), 681-694. 
Storper, M., \& Venables, A. J. (2004). Buzz: Face-to-face contact and the urban economy. Journal of Economic Geography, 4(4), 351-370.

Stough, R., Welter, F., Block, J., Wennberg, K., \& Basco, R. (2015). Family business and regional science: "Bridging the gap." Journal of Family Business Strategy, 6(4), 208-218.

Suwala, L. (2014). Kreativität, Kultur und Raum: Ein wirtschaftsgeographischer Beitrag am Beispiel des kulturellen Kreativitätsprozesses. Switzerland: Springer.

Suwala, L. (2019). Management Geography - Standortentscheidungen, Netzwerke und Raumbilder nordamerikanischer und japanischer Familienunternehmen. Wiesbaden: Springer.

Suwala, L. (2020). Space Concepts, Re-figuration of Spaces and Comparative Research - Perspectives from Economic Geography and Regional Economics. Forum Qualitative Sozialforschung ( FQS).

Suwala, L., \& Kitzmann, R. (2019), Ein zweites Leben als Asia-Großmarkt: Das Dong Xuan Center. In B. Lichtenberg (Ed.), Wirtschaftsstandort HerzbergstraßeTradition mit Zukunft (pp. 25-28). Germany: Bezirksamt Lichtenberg.

Suwala, L., \& Kulke, E. (2017). Between embeddedness and otherness: Internationalisation of grocery retailers in emerging markets. In M. Fuchs, S. Henn, M. Franz, \& R. Mudambi (Eds.), Managing Culture and Interspace in Cross-Border Investments: Building a Global Company (pp. 146-157). London: Routledge.

Suwala, L., Kulke E., \& Gade K. (2018). Zentralamerika (Nicaragua, Honduras, Guatemala, Belize) Bericht zur Hauptexkursion 2017. Berlin: Arbeitsberichte Geographisches Institut Heft 195.

Suwala, L., \& Micek, G. (2018). Beyond clusters? Field configuration and regional platforming: The Aviation Valley initiative in the Polish Podkarpackie region. Cambridge Journal of Regions, Economy and Society, 11(2), 353-372.

Suwala, L., \& Oinas, P. (2012). Management geography: A conceptual framework. Paper presented at the International Geographical Congress (IGC). Cologne.

Suwala, L., \& Schlunze, R. (2019). The stony path of management geography. SIEM Bulletin, 1(1), 1-5.

Taylor, M. J. (1975) Organizational growth, spatial interaction and location decision-making. Regional Studies, 9(4), 313-323.

Taylor, M., \& Asheim, B. (2001). The concept of the firm in economic geography. Economic Geography, 77(4), 315-328.

Taylor, M., \& Oinas, P. (2006). (eds.), Understanding the Firm: Spatial and Organisational Dimensions. Oxford: Oxford University Press.

Torre, A., \& Wallet, F. (2014). The role of proximity relations in regional and territorial development processes. In A. Torre \& F. Wallet (Eds.), Regional Development and Proximity Relations (pp. 1-44). Cheltenham: Edward Edgar.

Townroe, P. M. (1969). Locational choice and the individual firm. Regional Studies, 3(1), 15-24.

Trigilia, C. (1986). Small-firm development and political subcultures in Italy. European Sociological Review, 2(3), 161-175.

Trigilia, C. (1990), Work and politics in the Third Italy's industrial districts. In F. Pyke, G. Becattini, \& W. Sengenberger (Eds.), Industrial Districts and Inter-firm Co-operation in Italy (pp. 160-184). Geneva: International Institute for Labour Studies. 


\section{Rodrigo Basco and Lech Suwala}

Wei, Y. D., Li, W., \& Wang, C. (2007). Restructuring industrial districts, scaling up regional development: A study of the Wenzhou model, China. Economic Geography, 83(4), 421-444.

Trip, J. J., \& A. Romein (2010). Creative city policy: Bridging the gap with theory. Paper presented at the Eighth European Urban and Regional Studies Conference 'Repositioning Europe in an era of global transformation', Vienna, 15-17 September 2010.

Westhead, P., \& Cowling, M. (1998). Family firm research: The need for a methodological rethinking. Entrepreneurship Theory and Practice, 23(1), 31-56.

Westlund, H., \& Adam, F. (2010). Social capital and economic performance: A meta-analysis of 65 studies. European Planning Studies, 18(6), 893-919.

Wigren, C. (2003). The Spirit of Gnosjö-The Grand Narrative and Beyond. JIBS Dissertation Series, 017. Jönköping: Jönköping International Business School.

Yanagisako, S. J. (2002). Producing Culture and Capital: Family Firms in Italy. Princeton, NJ: Princeton University Press.

Yeung, H. W. C. (2000). Limits to the growth of family-owned business? The case of Chinese transnational corporations from Hong Kong. Family Business Review, 13(1), 55-70.

Yeung, H. W. C., \& Soh, T. M. (2000). Corporate governance and the global reach of Chinese family firms in Singapore. Seoul Jounral of Economics, 13(3), 301-334.

Zhou, Y. (1996). Inter-firm linkages, ethnic networks, and territorial agglomeration: Chinese computer firms in Los Angeles. Papers in Regional Science, 75(3), 265.

Zhou, H., He, F., \& Wang, Y. (2017). Did family firms perform better during the financial crisis? New insights from the S\&P 500 firms. Global Finance Journal, $33,88-103$. 